Rençber, I.., Koparal, C. (2021). "The Mediating Roles of Organizational Commitment and Job Satisfaction in the Effect of Career Satisfaction on Organizational Citizenship Behavior", Eskişehir Osmangazi Üniversitesi iiBF Dergisi, 16(2), $276-299$.

Doi: $10.17153 / o g u i i b f .875961$

Başvuru: 07.02.2021 Kabul: 30.03.2021

Araştırma Makalesi/Research Article

\title{
The Mediating Roles of Organizational Commitment and Job Satisfaction in the Effect of Career Satisfaction on Organizational Citizenship Behavior ${ }^{1}$
}

\begin{tabular}{|c|c|}
\hline $\begin{array}{l}\text { Kariyer Tatmininin Örgütsel Vatandaşlık Davranışına } \\
\text { Etkisinde Örgütsel Bağıııı̆ın ve İş Tatmininin Aracılık } \\
\text { Rolü }\end{array}$ & $\begin{array}{l}\text { The Mediating Roles of Organizational Commitment } \\
\text { and Job Satisfaction in the Effect of Career Satisfaction } \\
\text { on Organizational Citizenship Behavior }\end{array}$ \\
\hline Öz & Abstract \\
\hline $\begin{array}{l}\text { Bu çalışma, kariyer tatmininin örgütsel vatandaşlık } \\
\text { davranışına etkisinde örgütsel bağııığın ve iş tatmininin } \\
\text { aracılık rolünü araştırmayı amaçlamaktadır. Araştırma, } \\
\text { İzmir/Kemalpaşa Organize Sanayi Bölgesinde faaliyet } \\
\text { gösteren özel sektör işletmelerden kolayda örnekleme } \\
\text { yöntemi ile seçilen beyaz yakalı çalışanlar üzerinde } \\
\text { gerçekleştirilmiştir. Değişkenler arasındaki ilişkilerin } \\
\text { incelenmesine yönelik olarak değerlendirmeye alınan } \\
308 \text { adet anketin verileri, yapısal eşitlik modellemesi } \\
\text { tekniği kullanılarak ıM AMOS } 24 \text { istatistik programı ile } \\
\text { analiz edilmiştir. Elde edilen bulgular, kariyer tatmininin } \\
\text { örgütsel vatandaşlık davranışı boyutlarından } \\
\text { yardımseverlik, nezaket tabanlı bilgilendirme ve } \\
\text { centilmenlik üzerinde olumlu etkisinin bulunduğunu } \\
\text { göstermiştir. Ayrıca bu ilişkiye yalnızca duygusal bağlılık } \\
\text { ve iş tatmini değişkenlerinin aracılık ettikleri tespit } \\
\text { edilmiştir. }\end{array}$ & $\begin{array}{l}\text { This study aims to examine whether organizational } \\
\text { commitment and job satisfaction have mediating roles in } \\
\text { the effect of career satisfaction on organizational } \\
\text { citizenship behavior. The study was carried out on white- } \\
\text { collar workers who were chosen through convenience } \\
\text { sampling from private sector companies operating in } \\
\text { İmir/Kemalpaşa Organized Industrial Zone, Turkey. The } \\
\text { data from } 308 \text { employees were analyzed via structural } \\
\text { equation modeling techniques at the IBM Amos } 24 \\
\text { statistical program. The results indicated that career } \\
\text { satisfaction had a positive effect on the sportsmanship, } \\
\text { courtesy, and altruism dimension of organizational } \\
\text { citizenship behavior. Also, it was found that job } \\
\text { satisfaction and only affective commitment had } \\
\text { mediating roles in this relationship. }\end{array}$ \\
\hline $\begin{array}{l}\text { Anahtar Kelimeler: Kariyer Tatmini, Örgütsel Vatandaşlık } \\
\text { Davranışı, Örgütsel Bağlılık, İş Tatmini, Yapısal Eşitlik } \\
\text { Modellemesi }\end{array}$ & $\begin{array}{l}\text { Keywords: Career Satisfaction, Organizational } \\
\text { Citizenship Behavior, Organizational Commitment, Job } \\
\text { Satisfaction, Structural Equation Modeling }\end{array}$ \\
\hline JEL Kodları: O15, D23, C30 & JEL Codes: 015, D23, C30 \\
\hline
\end{tabular}

\begin{tabular}{cc}
\hline \hline $\begin{array}{c}\text { Araştırma ve } \\
\text { Yayın Etiği } \\
\text { Beyanı }\end{array}$ & $\begin{array}{c}\text { Bu çalışma, 27.10.2017 tarih ve } 106222 \text { protokol sayılı Anadolu Üniversitesi Sosyal ve Beşerî Bilimler Araştırma } \\
\text { ve Yayın Etiği Kurulu Karar Belgesi ile bilimsel araştırma ve yayın etiği kurallarına uygun olarak hazırlanmıştır. } \\
\begin{array}{c}\text { Yazarların } \\
\text { Makaleye Olan } \\
\text { Katkıları }\end{array} \\
\text { Çıkar Beyanı }\end{array}$ Yazarlar açısından ya da üçüncü taraflar açısından çalışmadan kaynaklı çıkar çatışması bulunmamaktadır. \\
\hline \hline
\end{tabular}

\footnotetext{
${ }^{1}$ This study is based on the doctoral dissertation of Ibrahim Rencber entitled "The Mediating Roles of Organizational Commitment and Job Satisfaction in the Effect of Career Satisfaction on Organizational Citizenship Behavior" which completed under the supervision of Prof. Dr. Celil Koparal at Anadolu University.

2 Dr., Anadolu University, Graduate School of Social Sciences, Department of Business Administration, Management and Organization, ibrahimrencber35@gmail.com

3 Prof. Dr., Anadolu University, Faculty of Economics and Administrative Sciences, Department of Business Administration, Management and Organization, ckoparal@anadolu.edu.tr
} 


\section{Introduction}

It is generally accepted that human resources are one of the most important factors increasing the success of organizations in an environment where production factors are almost similar. This situation has led to an increase in activities aimed at raising the level of satisfaction individuals have with the life of the organization. One of the goals of career management applied within the scope of these activities is to enable individuals to reach their career goals (Şimşek and Soysal, 2016). Individuals' internal assessments of the extent to which their career goals are achieved are expressed as career satisfaction (Ng and Feldman, 2014). Career satisfaction is a summary of individuals' entire work lives (Lounsbury, 2006) and is important because of its physiological, psychological, and sociological effects (Spurk et al., 2011). Career satisfaction is related not only to individuals but also to organizations. Because individuals who are satisfied with their careers contribute positively to efforts to increase organizational success ( $\mathrm{Ng}$ et al., 2005). The relationship between career satisfaction and some variables that are closely related to organizational success, such as performance (Trivellas et al., 2015), motivation (Abele and Spurk, 2009), and intention to leave (Joo and Park, 2010), has been proven by various studies.

Organizational success is crucial for organizations that want to achieve sustainable competitive advantage to keep up with environmental changes. It is not enough for the members of the organization to carry out only the activities in the official job definitions to increase organizational success. Therefore, there is a need for voluntary behaviors that goes beyond task performance. These behaviors, also called organizational citizenship behavior $(\mathrm{OCB})$, contribute to organizational effectiveness by shaping the corporate, social, and psychological context that balances the functioning of the activities and processes within the organization (Borman and Motowidlo, 1997). OCB supports increasing the sharing of knowledge and skills of individuals and thus reducing educational costs (Podsakoff and MacKenzie, 1997). Also, it facilitates the audit tasks of managers by developing feelings of responsibility in individuals and saves time and energy for performing other tasks (Bateman and Organ, 1983).

It is stated that career satisfaction is a strong source of motivation to produce positive outcomes for the individual and organization (Abele et al., 2011). Abele and Spurk (2009) found that individuals' subjective feelings about career success increase future efforts. This situation is consistent with the claim that motivation theories such as the Herzberg's twofactor theory, Maslow's hierarchy of needs, and Alderfer's ERG theory put forward that individual can be directed to certain behaviors by meeting their needs and expectations (Koçel, 2015). Besides, the positive behavior of individuals who perceive that their career needs are met coincides with the assumptions of social exchange theory (Yürür, 2019). Previous research has mainly focused on determining the predictors of career satisfaction (Judge et al., 1995; Nabi, 1999; Ng et al., 2005). But little has examined the relationship of career satisfaction with its outcome variables (Joo and Park, 2010; Karatepe, 2012). Since there is no research on this subject in the literature, it remains unclear whether career satisfaction affects organizational citizenship behaviors. Based on current theories and studies, the idea that career satisfaction can affect organizational citizenship behavior is the reason for this research. In this context, whether career satisfaction affects organizational citizenship behaviors that increase organizational effectiveness constitutes the main research problem. Another research question is whether there are mediating variables in the possible 
relationship between career satisfaction and OCB. To explain the nature of the relationship between these variables, job satisfaction, and organizational commitment variables were determined as mediator variables. The relationships between job satisfaction and organizational commitment and independent and dependent variables were determinant in the selection of mediator variables. Studies have shown that career satisfaction has significant relationships between job satisfaction (Kuchinke et al., 2008) and organizational commitment (Joo and Park, 2010). It was also found that there are significant relationships between OCB and job satisfaction (Tsai and $\mathrm{Wu}, 2010$ ) and organizational commitment.

As a result, the purpose of this research is to determine whether the career satisfaction of individuals has an impact on organizational citizenship behavior. Then, it is to investigate whether individuals' job satisfaction and organizational commitment have mediating roles in the possible relationship between career satisfaction and organizational citizenship behavior. In this context, firstly, information about the literature about research variables was presented. Then hypotheses were created about the expected relationships between variables. Finally, the findings obtained by structural equation modeling are discussed, the results and suggestions are presented.

\section{Literature Review}

\subsection{Career Satisfaction}

Although the foundations of the career concept date back to the 16th century, its scientific use has been later used (Çelik, 2016). Career is defined as "the individually perceived sequence of attitudes and behaviors associated with work-related experiences and activities over the span of the person's life" (Hall, 2002: 12). According to this definition, the career is a process, and it refers to the work-related activities that one has done all his life. In the definition, no direction is specified hierarchically about the career. Besides, by referring to the individual's attitudes and behaviors, the objective and subjective aspects of the career are emphasized. Career satisfaction is expressed as a sense of satisfaction perceived by the individual from his/her career as a whole (Lounsbury et al., 2008). Career satisfaction includes an extensive assessment of an individual's career-related expectations and gains throughout his/her life (Heslin, 2005).

Career satisfaction causes the individual to determine career goals according to their perceptions, values, and characteristics and to exhibit attitudes and behaviors in this direction (Ertürk, 2011). Attracting talented individuals to the organization, increasing the qualifications of the existing ones, and placing these individuals in the existing staff contribute to organizational success (Ng et al., 2005). Career satisfaction is important in terms of affecting the mental happiness and quality of life of individuals (Lounsbury et al., 2004). Individuals with career satisfaction are happier and motivated, thus they show higher performance (Peluchette, 1993). Also, a career is an effective tool in obtaining the financial power necessary for individuals to live the life they desire. This power helps people gain a social identity and status (Ertürk, 2011). Previous research has shown that career satisfaction is positive with performance, job satisfaction, organizational commitment, and life satisfaction; has shown that it is negatively associated with turnover and work-family conflict (Joo and Park, 2010; Simo et al., 2010; Dyke and Duxbury, 2011; Karatepe, 2012; Lounsbury et al., 2004; Martins et al., 2002). 


\subsection{Organizational Citizenship Behavior}

Based on Barnard's (1938) study, which he called the nature of organizations as a cooperative system, OCB is defined as "the behaviors that contribute to maintaining and enhancing the social and psychological context that supports task performance" (Organ, 1997: 95). In previous studies, OCB has been named with different concepts such as contextual performance (Borman and Motowidlo, 1993), extra-role behavior (Van Dyne et al., 1995), prosocial organizational behavior (Brief and Motowidlo, 1986), and organizational spontaneity (George and Brief, 1992). OCB has been discussed by many researchers in the literature and has been classified in different forms. In this research, the five-dimensional OCB classification of the Organ (1988), which has been accepted in a wider range in Turkey, was used.

OCB helps increase the productivity of managers and colleagues, use resources for more efficient purposes, coordinate activities between team members and workgroups, make the organization a more attractive place, attract and keep talented people in the organization, improve the stability of organizational performance, and improve the organization's ability to adapt to environmental changes (Podsakoff and MacKenzie, 1997). OCB lubricates the social mechanism of the organization by supporting cooperation, helpfulness, suggestions, gestures of goodwill, and altruistic behaviors among individuals (Smith et al., 1983). OCB positively affects the psychological health of individuals by creating a supportive organizational climate. It has been stated that these effects reduce the bad mood, desensitization, and burnout levels of individuals (Kumar et al., 2016: 600). It has been shown in several studies that OCB is related to various organizational variables such as performance, effectiveness, job satisfaction, organizational commitment, perceived fairness, leadership support, turnover, absenteeism, role overload, work-family conflict (Podsakoff and MacKenzie, 1997; Dash and Pradhan, 2014; Tsai and Wu, 2010; MacKenzie et al., 1998; Podsakoff and MacKenzie, 1994; Organ and Ryan, 1995; Netemeyer et al., 1997).

\subsection{Organizational Commitment}

Organizational commitment is defined as "a strong belief in and acceptance of the organization's goals and values; a willingness to exert considerable effort on behalf of the organization; and a strong desire to maintain membership in the organization" (Mowday et al., 1979: 226). Organizational commitment is generally classified as attitudinal, behavioral, and multiple commitment in the literature. Attitudinal commitment focuses on the process in which individuals evaluate the compliance of their values and goals with the values and goals of the organization (Meyer and Allen, 1991: 62). Behavioral commitment is largely related to the process by which individuals develop a sense of commitment to their behavior, rather than to an organization (Oliver, 1990: 20). The multiple commitment predicts the existence of different elements inside and outside the organization and that different levels of commitment to these elements can be developed (Reichers, 1985: 472).

Meyer and Allen (1991) approached organizational commitment as a three-component model. The first component is the affective commitment which the individual goes on the organization with emotional feelings. Second, continuance commitment bases on the costs of leaving the organization. Finally, normative commitment reflects the obligation to remain at the organization. These three components are psychological states that individuals may experience at different degrees (Allen and Meyer, 1990). The transformation like the work and organizational structures leaves organizations faced with the stress of doing more with 
fewer resources. In such a situation, organizations that want to achieve a sustainable competitive advantage need to establish a strong business environment in which their members are in solidarity (Luthans, 2011: 146). For this reason, the concept of organizational commitment is one of the issues that administrators carefully consider, and its importance is constantly increasing. It has been shown in the previous studies that organizational commitment is positively associated with life satisfaction, organizational justice, performance, job satisfaction, job involvement, leader-member exchange, and OCB, while is negatively associated with turnover intention, role ambiguity, and role conflict (Chughtai and Zafar 2006; Meyer et al., 2002; Mathieu and Zajac, 1990; Kacmar et al., 1999; Zeinabadi, 2010; Jain et al., 2013).

\subsection{Job Satisfaction}

Job satisfaction has been defined as "a positive feeling arising from the evaluation of job characteristics" (Robbins and Judge, 2013: 79). This assessment includes individual expectations for many job-related dynamics such as wage, promotion, career opportunities, job security, management, colleagues, the importance of the job, job autonomy, and feedback. It is stated that job satisfaction occurs when these expectations and results match.

Job satisfaction is one of the most important determinants of successful organizations (Jalagat, 2016: 37-38). Today, a satisfied individual is one of the most important contributions to high efficiency and productivity for organizations struggling to survive in a competitive environment. A satisfied individual is more productive, does not absenteeism, and also the intention to quit is lower than other individuals (Çekmecelioğlu, 2006; Altaş and Çekmecelioğlu, 2007). Job satisfaction also plays an important role in keeping and attracting qualified individuals to the organization. This contributes to the competitive advantage by reducing many direct and indirect costs. One of the best indicators of job disruption in an organization is job dissatisfaction. Job dissatisfaction leads to undesirable behaviors such as turnover, absenteeism, lateness, plagiarism, violence, and low citizenship behavior (Vecchio, 2006: 273; Newstrom and Davis, 2002: 213). Research has proven that job satisfaction is associated with various organizational variables such as performance, organizational commitment, socialization, OCB, psychological well-being, role conflict, role load, burnout, absenteeism, intention to leave (Tett and Meyer, 1993; Judge et al., 2001; Wright and Bonett, 2007; Yang, 2010; Tsai and Wu, 2010; Rageb et al., 2013).

\section{Hypotheses}

\subsection{Career Satisfaction - Organizational Citizenship Behavior}

Career satisfaction is often the subject of research in the field of human resource management and organizational behavior. When the studies on career satisfaction in the literature are analyzed, it is seen that the antecedents of career satisfaction are mostly examined (Judge et al., 1995; Rasdi, Ismail and Garavan, 2011; Hirschi, Nagy, Baumeler, Johnston and Spurk, 2017), however, there are a limited number of studies on the consequences of career satisfaction. In one of these few studies, Joo and Park (2010) showed that career satisfaction negatively related to turnover intention of employees in companies operating in Korea. Karatepe (2012) revealed that career satisfaction fully mediated the impact of perceived organizational support on performance outcomes. According to his study, hotel employees who are satisfied with their careers provide quality services to customers and respond to service failures successfully. In the study conducted by Lounsbury et al. (2004) 
on information science specialists, a positive relationship was found between career satisfaction and life satisfaction.

These results coincide with the basic assumption of the social exchange theory. According to Gouldner (1960), a social exchange relationship is based on reciprocity. The benefits of the organization create a feeling of necessity in the individual, so cause it to respond. This response manifests itself as the individual exhibiting useful attitudes and behaviors to the organization (Yürür, 2019). One of the behaviors that benefit the organization, OCB includes volunteering participation in activities that are beyond official job definitions and helping and cooperating with other organization members while performing these activities (Borman, and Motowidlo, 1997). In this context, it is expected that individuals whose career expectations are met by the organization can respond to the organization by exhibiting organizational citizenship behaviors. Therefore, the following hypothesis was proposed:

\section{H1: Career satisfaction has a positive effect on organizational citizenship behavior.}

\subsection{Career Satisfaction - Job Satisfaction}

While career satisfaction is the sense of satisfaction towards the entire career of the individual, job satisfaction is the positive attitude of the individual towards his job (Williamson, Pemberton and Lounsbury, 2005). Accordingly, while career satisfaction includes a broader assessment of the individual's life-related expectations and achievements, job satisfaction includes a narrower assessment of the individual's expectations and achievements regarding his current job (Heslin, 2005; Lounsbury, 2006). Therefore, although job satisfaction contributes to career satisfaction, they are conceptually different structures (Heslin, 2005). In the study conducted by Kuchinke, Kang and Oh (2008) on middle-level employees in different sectors in Korea, career satisfaction was a positive correlation with job satisfaction. Dyke and Duxbury (2011) found that subjective career success played an important role in individuals' attitudes (job satisfaction, intention to turnover, and organizational commitment). Consequently, in literature, it is seen that there is a positive relationship between the variables in the few studies conducted on career satisfaction and job satisfaction. Based on the discussion above, the following hypothesis was suggested:

H2: Career satisfaction has a positive effect on job satisfaction.

\subsection{Job Satisfaction - Organizational Citizenship Behavior}

Job satisfaction is an affirmative feeling that occurs as a result of the assessment of job features (Robbins and Judge, 2013). This assessment includes individual expectations for many work-related dynamics, such as the nature of the job, income, promotion, working conditions, organizational climate. It is stated that job satisfaction is realized when these expectations and results obtained match (Jalagat, 2016). The positive relationships between job satisfaction and OCB have been revealed through several studies (Netemeyer et al., 1997; Foote, and Tang, 2008; Zeinabadi, 2010; Tsai and Wu, 2010). In these studies, it was seen that the employees who are satisfied with their work tend to display more OCB. In other words, individuals who are satisfied with their careers exhibit more behaviors like helping their colleagues, following the rules and regulations of the organization, preventing problems that may occur, fulfilling their duties and responsibilities without complaining, actively participating in organizational activities and giving opinions (Podsakoff et al., 2000).

This relationship between job satisfaction and $O C B$ has been tried to be explained by theoretical approaches such as expectation theory (Vroom, 1964), the norm of reciprocity 
(Gouldner, 1960), psychological contract theory (Rousseau, 1995) and social exchange theory (Blau, 1964; Emerson, 1976). Although each theory deals with the subject from different perspectives, it is based on the idea that individuals whose expectations are met will be satisfied and, in turn, will perform beneficial behaviors to the organization (Organ and Ryan, 1995; Konovsky and Pugh, 1994). In this context, the H3 hypothesis was proposed to demonstrate whether the individual with job satisfaction exhibits organizational citizenship behaviors.

\section{H3: Job satisfaction has a positive effect on organizational citizenship behavior.}

It has been revealed that job satisfaction is associated with many organizational variables as dependent and independent variables (Cantarelli, Belardinelli and Belle, 2016). In some studies, it is considered as a variable mediating the individual's attitudes and behaviors. Bayarçelik and Fındıklı (2016) found in their research on public and private bank employees that job satisfaction had a mediating effect between perceived organizational justice and intention to turnover. Similarly, in a study conducted on medical university members, it was stated that job satisfaction was the mediator in the relationship between emotional intelligence and perceived general health (Yuan, Tan, Huang and Zou, 2014). Hence, the H4 hypothesis was created to find out whether job satisfaction had a mediating role in the possible effect of career satisfaction on OCB.

H4: Job satisfaction has a mediating effect on the relationship between career satisfaction and organizational citizenship behavior.

\subsection{Career Satisfaction - Organizational Commitment}

One of the individual's job-related attitudes is organizational commitment. According to Luthans (2011), organizational commitment is an attitude that reflects the loyalty of individuals to the organization. This attitude affects the decisions of the individuals to continue or not to continue their membership by defining their relationships with the organization. In the literature, the three-component organizational commitment model is generally accepted. Individuals who feel affective commitment stay at the organization voluntarily, individuals who feel continuance commitment stay in the organization due to the high costs of leaving, individuals who feel normative commitment stay at the organization due to familial, cultural, and organization values (Allen and Meyer, 1990). In studies conducted with the perspective of social exchange regarding the correlation between these variables, it is stated that affective commitment is closer to the relationship of social exchange. Because it is stated that the individual who perceives positive organizational output develops commitment in response. Unlike other commitment components, continuance commitment is more like an economic exchange relationship than a social exchange relationship (Yürür, 2019).

When the studies conducted on the above variables in the literature are examined, a positive correlation was provided between career satisfaction and affective commitment in a study conducted on employees in Korea (Joo and Park, 2010). Similarly, it was indicated that career satisfaction had a positive effect on the hotel staff's affective commitment (Hsu and Tsai, 2014). In the study conducted by Simo et al. (2010), subjective career success was associated positively with affective commitment but was associated negatively with continuance commitment. Accordingly, individuals perceive subjective career success as a result of the opportunities offered by the organization and therefore feel effectively attached 
to the organization. Employees with a high continuance commitment feel that their choices are more externally controlled, and therefore if there is better salary, promotion, etc. opportunities, they end their relationship with the organization. H5, therefore, was hypothesized.

H5: Career satisfaction has a positive effect on affective commitment ( $\mathrm{H} 5 \mathrm{a}$ ) and normative commitment ( $\mathrm{H} 5 \mathrm{~b})$ and has a negative effect on continuance commitment ( $\mathrm{H} 5 \mathrm{c}$ ).

\subsection{Organizational commitment - Organizational citizenship behavior}

In studies conducted to determine the relationship between organizational commitment and $O C B$, a positive strong relationship was found between $O C B$ and affective commitment. There is a relatively weak but positive relationship between $O C B$ and normative commitment. A negative relationship or no relationship has been found between the OCB and continuance commitment (Meyer et al., 2002; Feather and Rauter, 2004; Motaung and Radebe, 2018; Grego-Planer, 2019). Accordingly, individuals who are emotionally attached to the organization voluntarily support the organization. Individuals who have a normative commitment to the organization continue their membership in the organization due to social or cultural norms. Individuals who are attached with continuance commitment to the organization have an economic-based relationship with the organization and they end this relationship if there are better alternatives. One of the issues that distinguish between social exchange and economic exchange is the nature of the resources that are subject to exchange. Economic resources may be the subject of both economic and social exchange, but the relationship between the individual and the organization involves more emotional and social resources (Shore, Tetrick, Lynch and Bark, 2006; Yürür, 2019). For this reason, individuals who are committed to an affective and normative commitment to the organization are expected to exhibit organizational citizenship behaviors to demonstrate their gratitude (Meyer et al., 2002; Gautam, Van Dick, Wagner, Upadhyay and Davis, 2005). Hence, the H6 hypothesis was proposed between the components of organizational commitment and OCB.

H6: Affective commitment ( $\mathrm{H6a}$ ) and normative commitment ( $\mathrm{H} 6 \mathrm{~b})$ have positive effects on citizenship behavior; continuance commitment (H6c) has a negative effect on citizenship behavior.

Organizational commitment is considered as a result of social exchange, and in some studies, it is also considered as a variable that mediates positive attitudes and behaviors in the individual in response to the positive actions of the organization (Yürür, 2019). Prasetio et al. (2017) showed that organizational commitment contributes to the effect of job satisfaction on $\mathrm{OCB}$ as a mediator. A meta-analysis study demonstrated that organizational commitment mediated the relationship between justice and both task performance and organizational citizenship behavior (Colquitt, Scott, Rodell, Long, Zapata, Conlon and Wesson, 2013). In this study, the $\mathrm{H} 7$ hypothesis was suggested to find out whether organizational commitment had a mediating role in the possible effect of career satisfaction on OCB.

H7: Affective commitment, normative commitment, and continuance commitment have mediating effects on the relationship between career satisfaction and organizational citizenship behavior.

The model developed in accordance with research hypotheses is shown in Figure 1. Accordingly, the independent variable of the research is career satisfaction, while the 
dependent variable is organizational citizenship behavior. Job satisfaction and organizational commitment are mediator variables.

Figure 1: Research Model

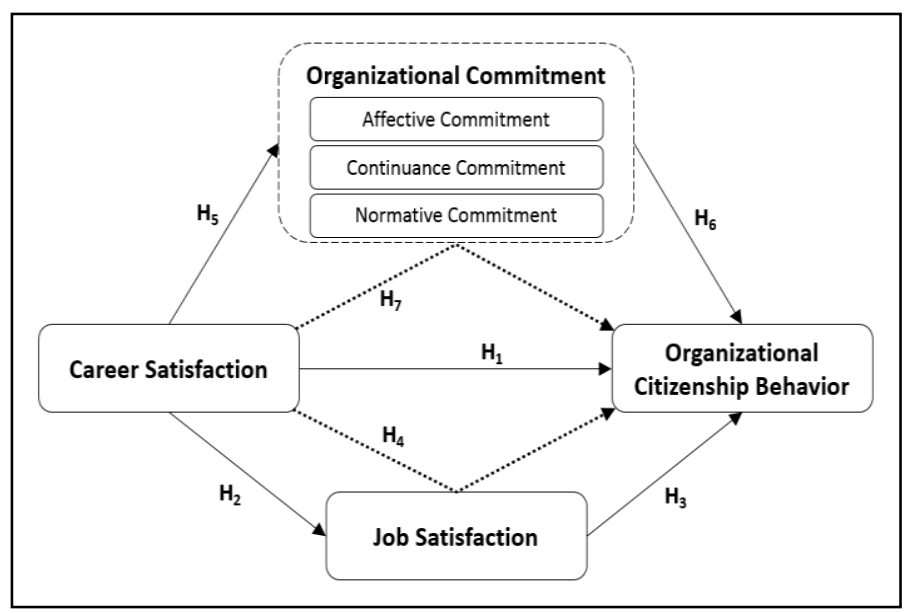

\section{Method}

\subsection{Sample}

The study was carried out on white-collar workers who were chosen through convenience sampling from private sector companies operating in İzmir/Kemalpaşa Organized Industrial Zone, Turkey. In this process, the analyses were carried out on 308 questionnaires.

While the proportion of male participants is about $60 \%$, the proportion of women is $40 \%$. $62.7 \%$ of the participants were married, while $36 \%$ were single. The majority of the participants were between the ages of $29-38$, with a percentage of $42.2 \%$. Approximately $53 \%$ of the participants had a bachelor's degree. $41.2 \%$ of the participants were managers, while $56.5 \%$ were non-manager. $66.6 \%$ of the participants had job tenure in the current organization of $0-10$ years. Finally, it is seen that $32.1 \%$ of the participants were in the food sector.

\subsection{Scales}

A questionnaire was used to obtain data in the study. While creating the survey scales, the literature was scanned, and the scales that were widely referenced and adapted to Turkish were determined. Except for demographic statements, all scales were answered on a 5-point scale (from strongly disagree to strongly agree).

The questionnaire, its structure, length, and comprehensibility evaluated by the academicians at Anadolu University. Thus, the research design error was tried to be prevented. According to the feedback received, the questionnaire was reorganized, and a pilot study was conducted on twenty-one white-collar employees. According to these results, the survey was implemented.

Career Satisfaction: For the measurement of career satisfaction variable, a 5-item scale developed by Greenhaus et al. (1990) and adapted to Turkish by Avcı and Turunç (2012) was used. 
Organizational Citizenship Behavior: OCB scale used in this study was developed by Podsakoff, MacKenzie, Moorman and Fetter (1990), and adapted to Turkish by Bitmiş, Sökmen and Turgut (2014). The 24-item scale consists of five sub-factors as altruism, courtesy, conscientiousness, sportsmanship, and civic virtue.

Organizational Commitment: An 18-item scale developed by Meyer, Allen and Smith (1993) and adapted to Turkish by Wasti (2003) was used to measure organizational commitment. The scale consists of three sub-factors as affective, normative, and continuance commitment.

Job Satisfaction: A 5-item scale developed by Chen, Ku, Shyr, Chen and Chou (2009) and adapted to Turkish by Turunç and Çelik (2012) was used to measure job satisfaction.

\subsection{Data Analysis}

Data were analyzed with IBM SPSS 25 and IBM Amos 24 (Arbuckle, 2016) package programs. Since the scales adapted to Turkish were used in this study, Confirmatory Factor Analysis (CFA) was carried out to verify the research model with the collected data. Cronbach's $\alpha$ was used to determine the reliability of the scales. The direct and indirect causal effects among variables were tested via Structural Equation Modeling (SEM). The maximum likelihood estimation method was preferred because of the multivariate normal distribution of data (Schumacker and Lomax, 2004; Harrington, 2009). Hypotheses related to mediating effects were tested with bootstrapping (Hayes, 2009; Preacher and Hayes, 2008; Williams and MacKinnon, 2008).

\subsection{Confirmatory Factor Analysis (CFA)}

In the study, the scales of career satisfaction, organizational citizenship behavior, organizational commitment, and job satisfaction were subjected to CFA one by one, and their construct validity was tried to be verified with the collected data. In this validation process, items with factor loadings below 0.5 , producing high modification coefficients and crossloadings tendency, were excluded from the analysis. Additionally, each factor was represented with at least three items (Kline, 2016; Hair Jr., Black, Babin and Anderson, 2014). Table 2 presents the CFA results.

Firstly, the validity of the one-factor structure of the career satisfaction scale was tested with CFA. As a result of the analysis, it was decided to remove one item (CS4) from the scale and to make modifications between the items e15 and e16. The goodness-of-fit indices obtained in the final analysis indicated that the one-factor career satisfaction scale was validated.

The validity of the second level five-factor structure of the organizational citizenship behavior scale was tested with CFA. As a result of the analyzes, the second level three-factor structure of the scale was confirmed by the data of altruism (ALT2, ALT4, and ALT5), courtesy (COU1, COU2, and COU3) and sportsmanship (SPO2, SPO3, SPO4, and SPO5). The goodnessof-fit indices indicated that the second level three-factor organizational citizenship behavior scale was validated.

The validity of the one-factor structure of the job satisfaction scale was tested with CFA. As a result of the analysis, it was decided to remove one item (JS3) from the scale and to make modifications between the items e12 and e13. The goodness-of-fit indices indicated that the one-factor job satisfaction scale was validated. 
Finally, the three-factor structure of the organizational commitment scale was validated with CFA. As a result of the analysis, three items were removed from the affective commitment ( $A C 1, A C 2$, and $A C 6)$, two items were removed from the continuance commitment (CC2 and CC3), and three items were removed from the normative commitment (NC1, NC2, and NC3). The goodness-of-fit indices showed that the three-factor structure of the scale of organizational commitment was validated.

Table 1: CFA Results of Scales

\begin{tabular}{llllllllll}
\hline Scales & $\boldsymbol{x}^{\mathbf{2}}$ & $\boldsymbol{d f}$ & $\boldsymbol{x}^{\mathbf{2}} / \boldsymbol{d f}$ & $\boldsymbol{R M S E A}$ & $\boldsymbol{S R M R}$ & $\boldsymbol{N F I}$ & GFI & CFI \\
\hline Career Satisfaction & 2.93 & 1 & 2.93 & .07 & .01 & .99 & .99 & .99 \\
OCB & 88.80 & 32 & 2.77 & .07 & .05 & .96 & .94 & .97 & .99 \\
Job Satisfaction & 2.66 & 1 & 2.66 & .07 & .01 & .99 & .99 & .99 & .99 \\
Organizational Commitment & 58.88 & 32 & 1.84 & .05 & .05 & .94 & .96 & .97 \\
\hline
\end{tabular}

$\mathrm{p}>0.05, \mathrm{x}^{2}=$ Chi-Square, $\mathrm{df}=$ Degree of Freedom, RMSEA= Root Mean Square Error of Approximation, SRMR=

Standardized Root Mean Square Residual, NFI= Normed Fit Index, GFI=Goodness of Fit Index, CFI= Comparative Fit Index.

\subsection{Reliability Analysis}

Cronbach's $\alpha$ was used to measure the internal consistency of scales. The Cronbach's $\alpha$ coefficients and the number of the items in scales are illustrated in Table 3 . These results indicate that the scales are reliable.

Table 2: Reliability Analysis of Scales

\begin{tabular}{llll}
\hline Factors & Sub Factors & Cronbach's $\boldsymbol{\alpha}$ & Number of Items \\
\hline Career Satisfaction & - & .889 & 4 \\
OCB & Altruism & .845 & 3 \\
& Courtesy & .889 & 3 \\
& Sportsmanship & .886 & 4 \\
Organizational Commitment & Affective Commitment & .856 & 3 \\
& Continuance Commitment & .754 & 4 \\
& Normative Commitment & .727 & 3 \\
\hline \multirow{2}{*}{ Job Satisfaction } & - & .896 & 4 \\
\hline
\end{tabular}

\subsection{Correlation Analysis}

Table 3 indicates the results of the correlation analysis. These results showed that correlations between normative commitment and sportsmanship and continuance commitment were insignificant, but all other variables had statistically significant relationships with each other. It was seen that career satisfaction was positively correlated with all factors $(r=.194$ and $r=.485)$ except continuance commitment $(p<.01)$. The correlation coefficients between factors of organizational citizenship behavior ranged from $r=$ .378 to $r=.841(p<.01)$. Affective commitment had positive correlations with normative commitment $(r=.463)$ while had negative correlations with continuance commitment $(r=-$ .334). Normative commitment had no correlation with continuance commitment $(p<.01)$. Job satisfaction was negatively correlated with continuance commitment $(r=-.198)$, while it was positively correlated with other variables $(r=.241$ to $r=.797)(p<.01)$. 
Table 3: Correlation Analysis of Factors

\begin{tabular}{lcrrrrrr}
\hline Factors & $\mathbf{1}$ & $\mathbf{2}$ & $\mathbf{3}$ & $\mathbf{4}$ & $\mathbf{5}$ & $\mathbf{6}$ & $\mathbf{7}$ \\
\hline 1. Altruism & & & & & & & \\
2. Courtesy & $.841^{* *}$ & & & & & \\
3. Sportsmanship & $.378^{* *}$ & $.457^{* *}$ & & & & & \\
4. Affective Commitment & $.339^{* *}$ & $.230^{* *}$ & $.343^{* *}$ & & & & \\
5. Continuance Commitment & $-.211^{* *}$ & $-207^{* *}$ & $-.290^{* *}$ & $-.334^{* *}$ & & & \\
6. Normative Commitment & $.425^{* *}$ & $.307^{* *}$ & .108 & $.463^{* *}$ & .040 & \\
7. Career Satisfaction & $.363^{* *}$ & $.377^{* *}$ & $.216^{* *}$ & $.194^{* *}$ & $-.264^{* *}$ & $.425^{* *}$ \\
8. Job Satisfaction & $.398^{* *}$ & $.402^{* *}$ & $.241^{* *}$ & $.437^{* *}$ & $-.198^{* *}$ & $.797^{* *}$ & $.485^{* *}$ \\
\hline $\mathrm{N}=308,{ }^{* *} \mathrm{p}<.01$ & & & & & & &
\end{tabular}

\subsection{Testing the Hypotheses with Structural Model}

After validating the factorial structure of the scales, the hypotheses were tested on a structural model with the latent variable. To examine Hypothesis $\mathrm{H} 1$, a structural model was established in which career satisfaction and OCB. The goodness-of-fit indices indicated that structural model fit the data well $\left(x^{2}[73, N=308]=188.64, p<.01, x^{2} / d f=2.58, \operatorname{RMSEA}=.07\right.$, $\mathrm{SRMR}=.05, \mathrm{NFI}=.93, \mathrm{GFI}=.91, \mathrm{CFI}=.96)$. The analysis results are given in Table 4. According to these results, career satisfaction was a positive effect on organizational citizenship behavior $(\beta=.39, p<.01)$. Career satisfaction explained $16 \%$ of the variance in OCB. According to these findings, $\mathrm{H} 1$ was supported.

To test the hypotheses $\mathrm{H} 2, \mathrm{H} 3$, and $\mathrm{H} 4$, a structural model was established in which job satisfaction was a mediator variable. The analysis results are given in Table 4. According to SEM analysis, it was found that career satisfaction had a positive effect on job satisfaction ( $\beta=$ $.50, p<.01$ ) and explained $25 \%$ of the variance in job satisfaction. According to these findings, $\mathrm{H} 2$ was supported. Similarly, job satisfaction positively affects to OCB $(\beta=.31, \mathrm{p}<.01)$. According to these findings, $\mathrm{H} 3$ was supported. Career satisfaction explained $23 \%$ of the variance in OCB along with job satisfaction. Being acceptable of the goodness-of-fit indices indicates that the model had a good fit to the data $\left(x^{2}[129, N=308]=317.90, p<.01, x^{2} / d f\right.$ $=2.46, \mathrm{RMSEA}=.06, \mathrm{SRMR}=.05, \mathrm{NFI}=.92, \mathrm{GFI}=.89, \mathrm{CFI}=.95)$.

A path analysis based on the bootstrap method was conducted to examine the job satisfaction's mediating role in the effect of career satisfaction on OCB. The number of bootstrap samples was chosen in 5000 in the bootstrapping test. Based on the bootstrap analysis, it might be said that career satisfaction's indirect effect on organizational citizenship behavior through job satisfaction was significant $(\beta=.156,95 \% \mathrm{Cl}[.068, .259])$. The bootstrap lower and upper confidence intervals of indirect coefficients did not include a value of zero. These results indicated that the job satisfaction variable had a mediating role in the effect of career satisfaction on OCB. In this case, H4 was supported. 
Table 4: The Results of Structural Models

\begin{tabular}{|c|c|c|c|c|c|}
\hline \multirow{3}{*}{ Independent variables } & \multicolumn{5}{|c|}{ Dependent variables } \\
\hline & $\begin{array}{l}\text { Job } \\
\text { satisfaction }\end{array}$ & $\begin{array}{l}\text { Affective } \\
\text { commitment }\end{array}$ & $\begin{array}{l}\text { Continuance } \\
\text { commitment }\end{array}$ & $\begin{array}{l}\text { Normative } \\
\text { commitment }\end{array}$ & $\begin{array}{l}\text { Organizational } \\
\text { citizenship } \\
\text { behavior }\end{array}$ \\
\hline & 8 & 8 & 8 & 8 & 8 \\
\hline Career satisfaction $\left(\mathrm{H}_{1}\right)$ & - & - & - & - & $.39 * * *$ \\
\hline$R^{2}$ & - & - & - & - & .16 \\
\hline Career satisfaction $\left(\mathrm{H}_{2}\right)$ & $.50 * * *$ & - & - & - & $.24 * * *$ \\
\hline Job satisfaction $\left(\mathrm{H}_{3}\right)$ & - & - & - & - & $.31^{* * *}$ \\
\hline$R^{2}$ & .25 & - & - & - & .23 \\
\hline \multicolumn{6}{|c|}{$\begin{aligned} \text { Career satisfaction } \rightarrow> & \text { Job satisfaction } \rightarrow>\text { Organizational citizenship behavior }\left(H_{4}\right) \\
& \text { Indirect effect, } .156,[.068, .259]\end{aligned}$} \\
\hline Career satisfaction $\left(H_{5 a, b, c}\right)$ & - & $.20 * * *$ & - & $.37^{* * *}$ & - \\
\hline$R^{2}$ & - & .04 & - & .34 & - \\
\hline Career satisfaction & & & & & $.29 * * *$ \\
\hline Affective commitment $\left(\mathrm{H}_{6 a}\right)$ & - & - & - & $.39 * * *$ & $.19^{*}$ \\
\hline Normative commitment $\left(H_{6 b}\right)$ & - & - & - & - & $.18^{*}$ \\
\hline Continuance commitment $\left(H_{6 c}\right)$ & - & - & - & - & - \\
\hline$R^{2}$ & & & & & .25 \\
\hline
\end{tabular}

$\mathrm{N}=308, * \mathrm{p}<.05, * * \mathrm{p}<.01, * * * \mathrm{p}<.001$. Standardized beta coefficients are reported. $\mathrm{R}^{2}$ indicates the variance described. $\mathrm{Cl}$ : Confidence Interval. Bootstrap samples $=5000$.

To test the $\mathrm{H} 5, \mathrm{H} 6$, and $\mathrm{H} 7$ hypotheses, another structural model, was established in which organizational commitment sub factors were mediator variables. The results of the initial analysis showed that the model did not have sufficient fit because of low NFI value. Thereupon, correction suggestions for covariance and regression coefficients were scrutinized, and the model was revised by following these recommendations. In the revised model, the continuance commitment factor, which had a relatively low contribution to the model compared to other mediator variables, was excluded from the analysis. Similarly, according to correction suggestions, a regression path was drawn from affective commitment to normative commitment, and these two variables were associated. The analysis results are given in Table 4. According to the results of SEM, it was seen that career satisfaction affects affective commitment positively $(\beta=.20, p<.01)$ and normative commitment $(\beta=.37, p<$ .01). According to these findings, $\mathrm{H} 5 \mathrm{a}$ and $\mathrm{H} 5 \mathrm{~b}$ were supported. Normative commitment $(\beta=$ $.18, p<.05)$ and affective commitment $(\beta=.19, p<.05)$ positively affect to OCB. According to these findings, $\mathrm{H} 6 \mathrm{a}$ and $\mathrm{H} 6 \mathrm{~b}$ were supported. Career satisfaction explained $25 \%$ of the variance in $\mathrm{OCB}$ along with organizational commitment components (affective and normative commitment). The goodness-of-fit indices indicated that revised model fit to the data well $\left(x^{2}\right.$ $[161, \mathrm{~N}=308]=367.27, \mathrm{p}<.01, \mathrm{x}^{2} / \mathrm{df}=2.28, \mathrm{RMSEA}=.06, \mathrm{SRMR}=.05, \mathrm{NFI}=.90, \mathrm{GFI}=.89$, $\mathrm{CFI}=.94)$.

To examine the mediating roles of organizational commitment sub factors in the effect of career satisfaction on OCB, a path analysis based on the bootstrap method was conducted as described above. According to bootstrap analysis, career satisfaction's indirect effect on organizational citizenship behavior through commitment components was significant $(\beta=$ $.118,95 \% \mathrm{Cl}[.032, .207])$. These results showed that organizational commitment sub factors (affective and normative commitment) had mediating effects on the relationship between career satisfaction and $\mathrm{OCB}$. In this case, $\mathrm{H} 7$ was partially supported. 
Finally, the research model was tested holistically (the model in which job satisfaction and organizational commitment sub factors were mediator variables) through the structural model. According to the result of the analysis, the path coefficients from the continuance $(p=$ .091) and normative $(p=.249)$ commitment to OCB were insignificant. Therefore, the model was revised by dropping these variables (normative and continuance) from the model, and the analysis was repeated (Jöreskog and Sörbom, 2015). The revised model indicated a good fit to data $\left(\mathrm{x}^{2}[180, \mathrm{~N}=308]=440.82, \mathrm{p}<.01, \mathrm{x}^{2} / \mathrm{df}=2.44, \mathrm{RMSEA}=.06, \mathrm{SRMR}=.08, \mathrm{NFI}=\right.$ $.90, \mathrm{GFI}=.85, \mathrm{CFI}=.94)$. The revised structural model is given in Figure 2.

Figure 2: The Revised Structural Model

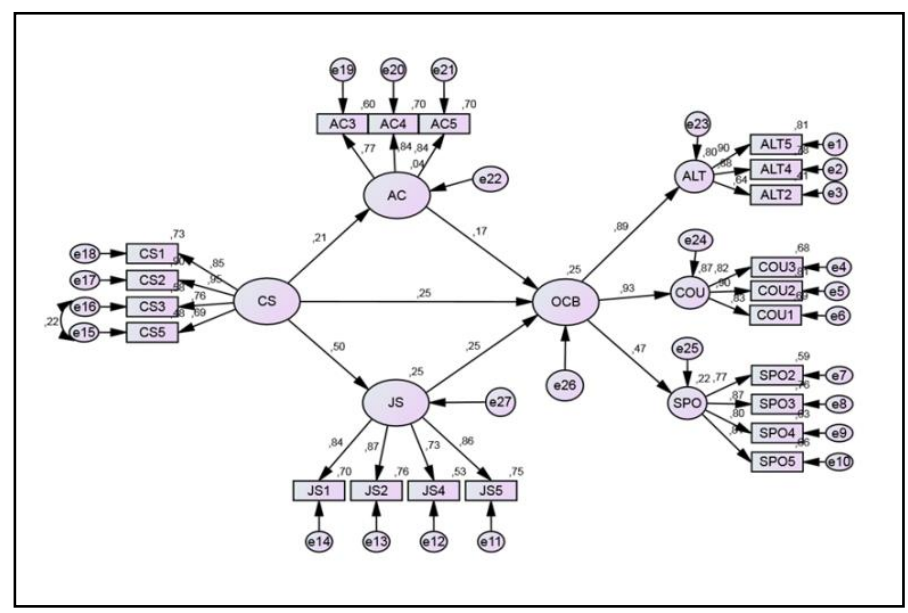

Note: Standardized beta coefficients are reported.

Based on these findings, it can be stated that job satisfaction and only affective commitment mediates the relationship between career satisfaction and OCB. Career satisfaction explained $25 \%$ of the variance in $\mathrm{OCB}$ along with affective commitment and job satisfaction (Figure 3).

Figure 3: The Results of the Revised Structural Model

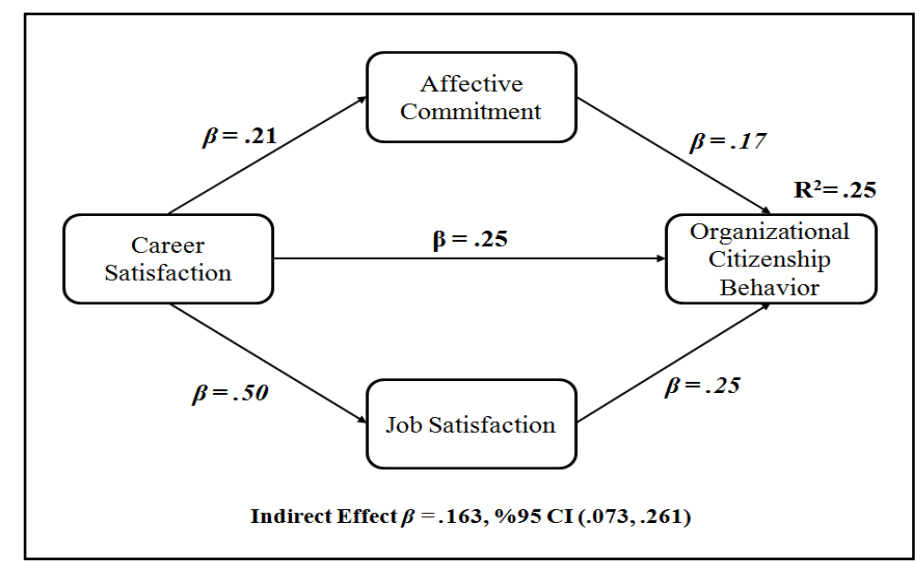

Note: Standardized beta coefficients are reported. R2 indicates the variance described. $\mathrm{Cl}$ : Confidence interval. 


\section{Discussion}

In this research, the effect of career satisfaction on organizational citizenship behaviors and mediating roles of job satisfaction and organizational commitment in this relationship was examined. The results supported the hypotheses.

As a result of the structural model created to examine the first hypothesis of the study, the positive effect of career satisfaction on the sportsmanship, courtesy, and altruism sub factors of the OCB was demonstrated. The results showed that individuals' satisfaction with their careers led to OCB. In other words, it is revealed that individuals who achieved their career goals tend to help voluntarily other members in organizational activities, to prevent conflicts, and to reduce tensions. Similarly, career satisfaction contributes positively to exhibiting behaviors aimed at avoiding problems within the organization. Also, individuals' career satisfaction increases behaviors such as fulfilling the duties and responsibilities by not complaining about workload, maintaining a positive attitude under challenging conditions, and taking a constructive manner. Although there is no study in the literature examining the correlation of career satisfaction with $\mathrm{OCB}$, the relationship between these variables with many other variables, such as leadership, organizational support, performance, intention to quit, supports the research results. It is considered that the generalizability of the relationship between these variables will increase thanks to the researches on this subject in the future.

The results of the structural model created to test the second hypothesis demonstrated that career satisfaction positively affected job satisfaction. This result indicates that individuals with career satisfaction are more satisfied with their jobs. Some studies conducted in the literature also support the results of the relationship between career satisfaction and job satisfaction (Williamson, Pemberton and Lounsbury, 2005; Dyke and Duxbury, 2011).

According to the results of the structural model created to test the third hypothesis, job satisfaction had a positive effect on OCB. This result shows that individuals who feel job satisfaction tend to exhibit more OCB. In other words, an increase in the positive attitudes of individuals towards their work leads to an increase in behaviors such as cooperation, respectful, and positive attitudes among the members of the organization as well as the prevention of conflicts and disruptions that may occur in organizational activities. These findings are coherent with the studies on these variables in the literature (Bateman and Organ, 1983; Tsai and Wu, 2010; Mehboob, and Bhutto, 2012).

In the fourth hypothesis of the study, it was examined whether job satisfaction mediated the effect of career satisfaction on OCB. The results of the path analysis based on the bootstrap method demonstrated that job satisfaction mediated the effect of career satisfaction on OCB. In other words, the satisfaction of individuals who achieve career goals causes them to exhibit more OCB. Some studies conducted in the literature support that job satisfaction mediates the relation between career satisfaction and organizational citizenship behavior (Nguni, Sleegers and Denessen, 2006; Podsakoff et al., 1990; Foote and Tang, 2008).

In the fifth hypothesis of the study, it was examined whether career satisfaction had a positive impact on affective and normative commitment and had a negative impact on continuance commitment. The structural model created in this context did not have sufficient fit to data. Afterward, the model was revised by following the recommendations for correction. In the revised model, the continuance commitment was removed from the model, and a regression path was drawn from affective commitment to normative commitment, and 
these two variables were associated. The results of the revised analysis revealed a positive effect of career satisfaction on individuals' affective commitment and normative commitment. Considering that each component of organizational commitment is realized as a result of different factors, individuals perceive that career satisfaction stems from the opportunities and investments offered by the organization. Therefore, they feel emotionally and normatively connected to the organization. The correlation between affective and normative commitment stems from the fact that factors contributing positively to affective commitment also contribute to individuals' sense of responsiveness (Meyer et al., 2002). The results obtained for the relationship between career satisfaction and organizational commitment was supported by the results presented by Simo et al. (2010). In this study, it was found that the perception of the success of individuals in their careers was positively associated with affective commitment and was negatively associated with continuance commitment. Similarly, in a study conducted by Joo and Park (2010), it was found that individuals providing a high level of career satisfaction showed an extra level of organizational commitment.

According to the sixth hypothesis's results, which was designed to determine the effects of affective, normative, and continuance commitment on $\mathrm{OCB}$, affective commitment, and normative commitment had a positive impact on OCB. These results indicated that individuals with high levels of affective and normative commitment tended to exhibit more organizational citizenship behavior. In other words, individuals who strongly feel a desire and an obligation to maintain the membership of the organization act more altruism, courtesy, and sportsmanship behaviors. While individual characteristics and work experiences are more effective in affective commitment, social and cultural factors are more effective in normative commitment. Therefore, it is expected that individuals who are connected to the organization with these types of commitment will exhibit more OCB (Meyer et al., 2002). Thus, the increase in the affective and normative commitment of individuals in a supportive organizational environment leads to more cooperation, solidarity, informing, and focusing positive side of events behaviors. These findings support the results of studies on organizational commitment and OCB (Meyer et al., 2002; Gautam, Van Dick, Wagner, Upadhyay and Davis, 2005).

In the seventh hypothesis of the study, it was examined whether affective commitment, normative commitment, and continuance commitment had mediating effects on the relationship between career satisfaction and $O C B$. The results of the analysis based on the bootstrap method showed that affective commitment and normative commitment had mediating effects on the relationship between career satisfaction and OCB. The individuals who have reached their career goals agree with the organization's purposes and values. When the individuals decide to maintain membership in the organization with a sense of gratitude, not for their interests, their behaviors of not complaining about workload, preventing possible problems, and helping their colleagues increase. These results were supported by the results presented by Çetin (2011). In that study, organizational commitment and job satisfaction mediated the in effects of personality and corporate culture on organizational citizenship behavior. Similarly, some studies conducted in the literature also support these results (Altaş and Çekmecelioğlu, 2007; Khan and Rashid, 2015).

Finally, a structural equation modeling was established to test the research model including all variables. According to the analysis's findings, affective commitment, and job 
satisfaction mediated the effect of career satisfaction on OCB. When the result is examined, it can be seen that affective commitment is felt more than other types of commitment because career satisfaction is an individual sense. Besides, it is stated that affective commitment is closer to the social exchange relationship between the individual and the organization compared to other commitment dimensions, and continuance commitment is more like an economic exchange relationship (Yürür, 2019: 268). This result is consistent with the view that factors such as work itself or job satisfaction affect the affective commitment, factors such as job alternatives or salary affect the continuance commitment, factors such as job loyalty norms or familial factors affect the normative commitment (Wasti, 2000). It was found that individuals who provided career satisfaction behave more organizational citizenship behaviors along with the perception created by the feeling of being emotionally connected to the organization and being satisfied with their jobs. In other words, the fact that individuals who have achieved their career goals are voluntarily a part of the organization and have a positive attitude towards their work plays a vital role in the behaviors that contribute to the effectiveness of the organization such as helping coworkers, preventing the emergence of problems, working without complaints despite the burdens and difficulties arising from their jobs.

\section{Conclusions}

Although there are many studies on the antecedents of career satisfaction in the literature, there are limited studies on the consequence of career satisfaction. In these studies, the relationship of career satisfaction with variables such as job satisfaction, organizational commitment, turnover intention, and performance has been examined. However, no research has been found concerning OCB. Thus, the effect of career satisfaction on OCB and the mediating roles of organizational commitment and job satisfaction in this relationship was examined for the first time. This study's findings proved that career satisfaction affected positively to $\mathrm{OCB}$, and affective commitment and job satisfaction had mediating roles in this relationship. This conclusion is coherent with the assumptions of social exchange theory, which is at the forefront of explaining attitudes and behaviors in organizational relations.

It is considered that this result between career satisfaction, which is essential in achieving individual and organizational goals, and organizational citizenship behaviors that increase the effectiveness and efficiency of the organization, will make a modest contribution to organizational behavior and human resource management (HRM) literature.

Also, it is thought that this result will support the measures that can be taken by the human resources units of organizations to increase the effectiveness and efficiency of individuals to achieve sustainable competitive advantage. Giving more attention to HRM practices that satisfy the career expectations of individuals increases the overall job satisfaction and affective commitment to the organization. It also causes to exhibit more organizational citizenship behaviors that contribute to the success of the organization.

\section{Future Research}

In future researches, it is thought that examining the mediation effect of different organizational variables such as the perception of justice and leadership will contribute significantly to the broader explanation of the relationship between career satisfaction and OCB. 
The present study was carried out on white-collar workers in private sector companies operating in the organized industrial zone. In future researches, it is considered that the use of data obtained from different sectors and different working groups will increase the generalizability of the findings.

\section{Limitations}

This research is limited to the white-collar employees who voluntarily participated in the study from private sector companies operating in İzmir/Kemalpaşa Organized Industrial Zone, Turkey. Therefore, the results of the research cannot be generalized outside the participants, and the representation power of the population is weak.

The research is a cross-sectional study covering the period between January 31,2018 , and May 17, 2019. The data could not be collected in different periods due to the difficulty of access to the participants. Research models examining the mediating effect give healthier results with longitudinal data. The fact that the cross-sectional designs do not always capture the actual mediating effect can limit the causality between the variables (Maxwell and Cole, 2007).

Since the variables are collected by the same method, there is a possibility of common method variance in the study. Many different procedural and statistical techniques are used to control method biases. The participants were told in the questionnaire that there was no right or wrong answer and that the answers would not be given to anyone. The participants were asked to respond in a way that reflected the truth as much as possible. Also, Harman's single-factor test was carried out in the study. This test is necessary but insufficient to reveal common method variance. As a result of the test, more than one structure was obtained and it was determined that none of the structures obtained included a significant part of the common variance (Podsakoff, MacKenzie, Lee and Podsakoff, 2003). 


\section{References}

Abele, A. E.; Spurk, D.; Volmer, J. (2011), "The Construct of Career Success: Measurement Issues and an Empirical Example", Zeitschrift für ArbeitsmarktForschung, Vol. 43: 195-206.

Abele, A. E.; Spurk, D. (2009), "How Do Objective and Subjective Career Success Interrelate Over Time?", Journal of Occupational and Organizational Psychology, Vol. 82 No. 4: 803-824.

Allen, N. J.; Meyer, J. P. (1990), "The Measurement and Antecedents of Affective, Continuance and Normative Commitment to the Organization", Journal of Occupational Psychology, Vol. 63 No. 1: 1-18.

Altaş, S. S.; Çekmecelioğlu, H. G. (2007), "iş tatmini, Örgütsel Bağlılık ve Örgütsel Vatandaşlık Davranışının İ̧̧ Performansı Üzerindeki Etkileri: Bir Araştırma”, Öneri Dergisi, C. 7 S. 28: 47-57.

Arbuckle, J. L. (2016), Amos (Version 24.0) [Computer Program]. Chicago: IBM SPSS.

AvcI, U.; Turunç, Ö. (2012), “Dönüşümcü Liderlik ve Örgüte Güvenin Kariyer Memnuniyetine Etkisi: Lider-Üye Etkileşiminin Aracılık Rolü", Uluslararası Alanya işletme Fakültesi Dergisi, C. 4 S. 2: 45-55.

Barnard, C. I. (1938), The Functions of the Executive. Cambridge, MA: Harvard University Press.

Bateman, T. S.; Organ, D. W. (1983), "Job Satisfaction and the Good Soldier: The Relationship Between Affect and Employee "Citizenship", The Academy of Management Journal, Vol. 26 No. 4: 587595.

Bayarçelik, E. B.; Fındıklı, M. A. (2016), "The Mediating Effect of Job Satisfaction on the Relation Between Organizational Justice Perception and Intention to Leave", Procedia-Social and Behavioral Sciences, Vol. 235: 403-411.

Bitmiş, M. G.; Sökmen, A.; Turgut, H. (2014), "Örgütsel Vatandaşlık Davranışı Ölçeği: Geçerlilik ve Güvenilirliğinin Yeniden Değerlendirilmesi", Gazi Üniversitesi iktisadi ve Idari Bilimler Fakültesi Dergisi, C. 16 S. 2: 1-14.

Blau, P. M. (1964), Exchange and Power in Social Life. New York: John Wiley.

Borman, W. C.; Motowidlo, S. J. (1993), "Expanding the Criterion Domain to Include Elements of Contextual Performance", Personnel Selection in Organizations, (Eds. N. Schmitt; W. C. Borman), Jossey Bass: San Francisco: 71-98.

Borman, W. C.; Motowidlo, S. J. (1997), "Task Performance and Contextual Performance: The Meaning for Personnel Selection Research", Human Performance, Vol. 10 No. 2: 99-109.

Brief, A. P.; Motowidlo, S. J. (1986), "Prosocial Organizational Behaviors", The Academy of Management Review, Vol. 11 No. 4: 710-725.

Cantarelli, P.; Belardinelli, P.; Belle, N. (2016), "A Meta-Analysis of Job Satisfaction Correlates in the Public Administration Literature", Review of Public Personnel Administration, Vol. 36 No. 2: 115-144.

Chen, F. C.; Ku, E. C. S.; Shyr, Y. H.; Chen, F. H.; Chou, S. S. (2009), "Job Demand, Emotional Awareness, and Job Satisfaction in Internships: The Moderating Effect of Social Support", Social Behavior and Personality, Vol. 37 No. 10: 1429-1440.

Chughtai, A.; Zafar, S. (2006), "Antecedents and Consequences of Organizational Commitment Among Pakistani University Teachers", Applied Human Resource Management Research, Vol. 1 No. 1: 39-64.

Colquitt, J. A.; Scott, B. A.; Rodell, J. B.; Long, D. M.; Zapata, C. P.; Conlon, D. E.; Wesson, M. J. (2013), "Justice at the Millennium, a Decade Later: A Meta-Analytic Test of Social", Journal of Applied Psychology, Vol. 98 No. 2: 199-236.

Çekmecelioğlu, H. G. (2006), "İ̧ Tatmini ve Örgütsel Bağlılık Tutumlarının İşten Ayrılma Niyeti ve Verimlilik Üzerindeki Etkilerinin Değerlendirilmesi: Bir Araştırma", İş, Güç Endüstri iliş̧kileri ve insan Kaynaklar. Dergisi, C. 8 S. 2: 153-168.

Çelik, A. (2016), "Kariyer Kavramı, Kapsamı ve Temel Boyutları", (Ed. M. Ş. Şimşek; A. Çelik; A. Akatay), Insan Kaynakları Yönetimi ve Kariyer Uygulamaları, Konya: Eğitim Yayınevi: 125-152. 
Çetin, F. (2011), Örgütsel vatandaşılı davranışlarının açıklanmasında örgütsel bağlııı, iş tatmini, kişilik ve örgüt kültürünün rolü, Doktora Tezi, Ankara Üniversitesi, Ankara.

Dash, S.; Pradhan, R. K. (2014), "Determinants and Consequences of Organizational Citizenship Behavior: A Theoretical Framework for Indian Manufacturing Organizations", International Journal of Business and Management Invention, Vol. 3 No. 1: 17-27.

Dyke, L.; Duxbury, L. (2011), "The Implications of Subjective Career Success", Journal for Labour Market Research, Vol. 43 No. 3: 219-229.

Emerson, R. M. (1976), "Social Exchange Theory", Annual Review of Sociology, Vol. 2: 335-362.

Ertürk, M. (2011), Insan Kaynakları Yönetimi, İstanbul: Beta Yayınları.

Feather, N. T.; Rauter, K. A. (2004), "Organizational Citizenship Behaviors in Relation to Job Status, Job Insecurity, Organizational Commitment and Identification, Job Satisfaction and Work Values", Journal of Occupational and Organizational Psychology, Vol. 77 No. 1: 81-94.

Foote, D. A.; Tang, T. L. P. (2008), "Job Satisfaction and Organizational Citizenship Behavior (OCB): Does Team Commitment Make a Difference in Self-Directed Teams?", Management Decision, Vol. 46 No. 6: 933-947.

Gautam, T.; Van Dick, R.; Wagner, U.; Upadhyay, N.; Davis, A. J. (2005), "Organizational Citizenship Behavior and Organizational Commitment in Nepal", Asian Journal of Social Psychology, Vol. 8 No. 3: 305-314.

George, J. M.; Brief, A. P. (1992), "Feeling Good-Doing Good: A Conceptual Analysis of The Mood at Work-Organizational Spontaneity Relationship", Psychological Bulletin, Vol. 112 No. 2: 310-329.

Gouldner, A. W (1960), "The Norm of Reciprocity: A Preliminary Statement", American Sociological Review, Vol. 25 No. 2: 161-178.

Greenhaus, J. H.; Parasuraman, S.; Wormley, W. M. (1990), "Effect of Race on Organizational Experiences, Job Performance Evaluations, and Career Outcomes", Academy of Management Journal, Vol. 33 No. 1: 64-86.

Grego-Planer, D. (2019), "The Relationship Between Organizational Commitment and Organizational Citizenship Behaviors in The Public and Private Sectors", Sustainability, MDPI, Vol. 11 No. 22: 1-20.

Hair, J. F.; Black, W. C.; Babin, W. J.; Anderson, R. E. (2014), Multivariate Data Analysis, $7^{\text {th }}$ Ed., Harlow, UK: Pearson.

Hall, D. T. (2002), Careers in and out of Organizations, Thousand Oaks, CA: Sage Publications, Inc.

Harrington, D. (2009), Confirmatory factor analysis, New York: Oxford University Press.

Hayes, A. F. (2009), "Beyond Baron and Kenny: Statistical Mediation Analysis in The New Millennium", Communication Monographs, Vol. 76 No. 4: 408-420.

Heslin, P. A. (2005), "Conceptualizing and Evaluating Career Success", Journal of Organizational Behavior, Vol. 26 No. 2: 113-136.

Hirschi, A.; Nagy, N.; Baumeler, F.; Johnston, C. S.; Spurk, D. (2017), "Assessing Key Predictors of Career Success: Development and Validation of The Career Resources Questionnaire", Journal of Career Assessment, Vol. 26 No. 2: 338-358.

Hsu, M. S.; Tsai, Y. Y. (2014), "Career Satisfaction and Organizational Commitment among Hotel Employees in Taiwan", Journal of Hotel \& Business Management, Vol. 3 No. 1.

Jain, A. K.; Giga, S. I.; Cooper, C. L. (2013), "Stress, Health, and Well-Being: The Mediating Role of Employee and Organizational Commitment", International Journal of Environmental Research and Public Health, Vol. 10 No. 10: 4907-4924.

Jalagat, R. (2016), "Job Performance, Job Satisfaction, and Motivation: A Critical Review of Their Relationship", International Journal of Advances in Management and Economics, Vol. 5 No. 6: 36-43. 
Joo, B.; Park, S. (2010), "Career Satisfaction, Organizational Commitment, and Turnover Intention: The Effects of Goal Orientation, Organizational Learning Culture, and Developmental Feedback", Leadership \& Organization Development Journal, Vol. 31 No. 6: 482-500.

Jöreskog, K. G.; Sörbom, D. (2015), LISREL 9.20 for Windows [Computer software], Scientific Software International, Inc.

Judge, T. A.; Cable, D. M.; Boudreau, J. W.; Bretz, R. D. (1995), "An Empirical Investigation of The Predictors of Executive Career Success", Personnel Psychology, Vol. 48 No. 3: 485-519.

Judge, T. A.; Thoresen, C. J.; Bono, J. E.; Patton, G. K. (2001), "The Job Satisfaction-Job Performance Relationship: A Qualitative and Quantitative Review", Psychological Bulletin, Vol. 127 No. 3: 376-407.

Kacmar, K. M.; Carlson, D. S.; Brymer, R. A. (1999), "Antecedents and Consequences of Organizational Commitment: A Comparison of Two Scales", Educational and Psychological Measurement, Vol. 59 No. 6; 976-994.

Karatepe, O. M. (2012), "Perceived Organizational Support, Career Satisfaction, and Performance Outcomes: A Study of Hotel Employees in Cameroon", International Journal of Contemporary Hospitality Management, Vol. 24 No. 5: 735-752.

Khan, S. K.; Rashid, M. Z. A. (2012), "The Mediating Effect of Organizational Commitment in The Organizational Culture, Leadership, and Organizational Justice Relationship with Organizational Citizenship Behavior: A Study of Academicians in Private Higher Learning Institutions in Malaysia", International Journal of Business and Social Science, Vol. 3 No. 8: 835-91.

Kline, R. B. (2016), Principles and practice of structural equation modeling, $4^{\text {th }}$ Ed., New York: The Gilford Press.

Koçel, T. (2015), İ̧̧letme Yöneticiliği, 16. Baskı, İstanbul: Beta Yayınları.

Konovsky, M. A.; Pugh, S. D. (1994), "Citizenship Behavior and Social Exchange", Academy of Management Journal, Vol. 37 No.3: 656-669.

Kuchinke, K. P.; Kang, H.; Oh, S. (2008), "The Influence of Work Values on Job and Career Satisfaction, and Organizational Commitment Among Korean Professional-Level Employees", Asia Pacific Education Review, Vol. 9 No.4: 552-564.

Kumar, M.; Jauhari, H.; Singh, S. (2016), "Organizational Citizenship Behavior and Employee WellBeing", The Indian Journal of Industrial Relations, Vol. 51 No. 4: 594-608.

Luthans, F. (2011), Organizational Behavior: An Evidence Based Approach, 12 ${ }^{\text {th }}$ Ed., New York: McGraw-Hill.

Lounsbury, J. W.; Park, S. H.; Sundstrom, E.; Williamson, J. M.; Pemberton, A. E. (2004), “Personality, Career Satisfaction, and Life Satisfaction: Test of a Directional Model", Journal of Career Assessment, Vol. 12 No. 4: 395-406.

Lounsbury, J. W. (2006), "Career Satisfaction", Encyclopedia of Career Development, (Eds. J. H. Greenhaus; G. A. Callanan), Sage Publications: Thousand Oaks, CA: 142-146.

Lounsbury, J.W.; Steel, R.P.; Gibson, L.W.; Drost, A.W. (2008), "Personality Traits and Career Satisfaction of Human Resource Professionals", Human Resource Development International, Vol. 11 No. 4: 351-366.

MacKenzie, S. B.; Podsakoff, P. M.; Ahearne, M. (1998), "Some Possible Antecedents and Consequences of In-Role and Extra-Role Salesperson Performance", Journal of Marketing, Vol. 62 No. 3: 87-98.

Martins, L. L.; Eddleston, K. A.; Veiga, J. F. (2002), "Moderators of The Relationship Between WorkFamily Conflict and Career Satisfaction", The Academy of Management Journal, Vol. 45 No. 2: 399-409.

Mathieu, J. E.; Zajac, D. M. (1990), "A Review and Meta-Analysis of The Antecedents Correlate, and Consequences of Organizational Commitment", Psychological Bulletin, Vol. 108 No. 2: 171-194. 
Maxwell, S. E.; Cole, D. A. (2007), "Bias in Cross-Sectional Analyses of Longitudinal Mediation", Psychological Methods, Vol. 12 No. 1: 23-44.

Mehboob, F.; Bhutto, N. A. (2012), "Job Satisfaction as a Predictor of Organizational Citizenship Behavior A Study of Faculty Members at Business Institutes", Interdisciplinary Journal of Contemporary Research in Business, Vol. 3 No. 9: 1447-1455.

Meyer, J. P.; Allen, N. J. (1991), "A Three-Component Conceptualization of Organizational Commitment", Human Resource Management Review, Vol. 1 No. 1: 61-89.

Meyer, J. P.; Allen, N. J.; Smith, C. A. (1993), "Commitment to Organizations and Occupations: Extension and Test of a Three-Component Conceptualization", Journal of Applied Psychology, Vol. 8 No. 4: 538-551.

Meyer, J. P.; Stanley, D. J.; Herscovitch, L.; Topolnytsky, L. (2002), "Affective, Continuance, and Normative Commitment to The Organization: A Meta-Analysis of Antecedents, Correlates, and Consequences", Journal of Vocational Behavior, Vol. 61 No. 1: 20-52.

Motaung, T. L.; Radebe, P. Q. (2019), "Organisational Commitment and Job Satisfaction as Antecedents of Organisational Citizenship Behavior", Journal of Economics and Behavioral Studies, Vol. 10 No. 6A: 109-122.

Mowday R. T.; Steers R. M.; Porter L. W. (1979), "The Measure of Organizational Commitment", Journal of Vocational Behaviour, Vol. 14 No. 2: 224-247.

Nabi, G. (1999), "An Investigation into The Differential Profile of Predictors of Objective and Subjective Career Success", Career Development International, Vol. 4 No. 4: 212-225.

Netemeyer, R. G.; Boles, J. S.; McKee, D. O.; McMurrian, R. (1997), "An Investigation into The Antecedents of Organizational Citizenship Behaviors in A Personal Selling Context", Journal of Marketing, Vol. 61 No. 3: 85-98.

Newstrom, J. W.; Davis, K. (2002), Organizational Behavior: Human Behavior at Work, $11^{\text {th }}$ Ed., Boston, Mass.: McGraw-Hill/Irwin.

Ng, T. W. H.; Eby, L. T.; Sorensen, K. L.; Feldman, D. C. (2005), "Predictors of Objective and Subjective Career Success: A Meta-Analysis", Personnel Psychology, Vol. 58 No. 2: 367-408.

Ng, T. W. H.; Feldman, D. C. (2014), "Subjective Career Success: A Meta-Analytic Review", Journal of Vocational Behavior, Vol. 85 No. 2: 169-179.

Nguni, S.; Sleegers, P.; Denessen, E. (2006), "Transformational and Transactional Leadership Effects on Teachers' Job Satisfaction, Organizational Commitment, and Organizational Citizenship Behavior in Primary Schools: The Tanzanian Case", School Effectiveness and School Improvement, Vol. 17 No. 2: 145177.

Oliver N. (1990), "Rewards, Investments, Alternatives and Organizational Commitment: Empirical Evidence and Theoretical Development", Journal of Occupational Psychology, Vol. 63 No. 1: 19-31.

Organ, D. W. (1997), "Organizational Citizenship Behavior: It's Constructed Clean-Up Time", Human Performance, Vol. 10 No. 2: 85-97.

Organ, D. W. (1988). Organizational Citizenship Behavior: The Good Soldier Syndrome, Lexington, MA, England: Lexington Books.

Organ, D. W.; Ryan, K. (1995), "A Meta-Analytic Review of Attitudinal and Dispositional Predictors of Organizational Citizenship Behavior", Personnel Psychology, Vol. 48 No. 4: 775-802.

Peluchette, J. V. E. (1993), "Subjective Career Success: The Influence of Individual Difference, Family, and Organizational Variables", Journal of Vocational Behavior, Vol. 43 No. 2: 198-208.

Podsakoff, P. M.; MacKenzie, S. B.; Moorman, R. H.; Fetter, R. (1990), "Transformational Leader Behaviors and Their Effects on Followers' Trust in Leader, Satisfaction, and Organizational Citizenship Behaviors", The Leadership Quarterly, Vol. 1 No. 2: 107-142. 
Podsakoff, P. M.; MacKenzie, S. B. (1994), "Organizational Citizenship Behaviors and Sales Unit Effectiveness", Journal of Marketing Research, Vol. 31 No. 3: 351-363.

Podsakoff, P. M.; MacKenzie, S. B. (1997), "Impact of Organizational Citizenship Behavior on Organizational Performance: A Review and Suggestion for Future Research", Human Performance, Vol. 10 No. 2: 133-151.

Podsakoff, P. M.; Mackenzie, S. B.; Paine, J. B.; Bachrach, D. G. (2000), “Organizational Citizenship Behaviors: A Critical Review of The Theoretical and Empirical Literature and Suggestions for Future Research", Journal of Management, Vol. 26 No. 3, 513-563.

Podsakoff, P. M.; MacKenzie, S. B.; Lee, J. Y.; Podsakoff, N. P. (2003), "Common Method Biases in Behavioral Research: A Critical Review of The Literature and Recommended Remedies", Journal of Applied Psychology, Vol. 88 No. 5: 879-903.

Prasetio, A. P.; Yuniarsih, T.; Ahman, E. (2017), "Job Satisfaction, Organizational Commitment, and Organizational Citizenship Behaviour in State-Owned Banking", Universal Journal of Management, Vol. 5 No. 1: 32-38.

Preacher, K. J.; Hayes, A. F. (2008), "Asymptotic and Resampling Strategies for Assessing and Comparing Indirect Effects in Multiple Mediator Models", Behavior Research Methods, Vol. 40 No. 3: 879-891.

Rageb, M. A.; Abd-El-Salam, E. M.; El-Samadicy, A.; Farid, S. (2013), “Organizational Commitment, Job Satisfaction, and Job Performance as a Mediator Between Role Stressors and Turnover Intentions a Study from an Egyptian Cultural Perspective", International Journal of Business and Economic Development, Vol. 1 No. 1: 34-54.

Rasdi, R. M.; Ismail, M.; Garavan, T. N. (2011), "Predicting Malaysian Managers' Objective and Subjective Career Success", The International Journal of Human Resource Management, Vol. 22 No. 17: 3528-3549.

Reichers, A. E. (1985), "A Review and Reconceptualization of Organizational Commitment", The Academy of Management Review, Vol. 10 No. 3: 465-476.

Robbins, S. P.; Judge, T. A. (2013), Organizational Behavior, 15th Ed., Pearson.

Rousseau, D. M. (1995), Psychological Contracts in Organizations: Understanding Written and Unwritten Agreements, Newbury Park, CA: Sage Publications, Inc.

Schumacker, R. E.; Lomax, R. G. (2004), A Beginner's Guide to Structural Equation Modeling, $2^{\text {nd }}$ Ed., Mahwah, NJ: Lawrence Erlbaum Associates, Inc.

Shore, L. M.; Tetrick, L. E.; Lynch, P.; Barksdale, K. (2006). "Social and Economic Exchange: Construct Development and Validation", Journal of Applied Social Psychology, Vol. 36 No. 4: 837-867.

Simo, P.; Enache, M.; Sallan Leyes, J. M.; Fernandez Alarcon, V. (2010), "Analysis of The Relation Between Subjective Career Success, Organizational Commitment, and The Intention to Leave The Organization", Transylvanian Review of Administrative Sciences, Vol. 29E: 144-158.

Smith, C. A.; Organ, D. W.; Near, J. P. (1983), “Organizational Citizenship Behavior: Its Nature and Antecedents", Journal of Applied Psychology, Vol. 68 No. 4: 653-663.

Spurk, D.; Abele, A. E.; Volmer, J. (2011), "The Career Satisfaction Scale: Longitudinal Measurement Invariance and Latent Growth Analysis", Journal of Occupational and Organizational Psychology, Vol. 84 No. 2: 315-326.

Şimşek, M. Ş.; Soysal, A. (2016), "Örgütlerde Kariyer Yönetimi", (Ed. M. Ş. Şimşek; A. Çelik; A. Akatay), Insan Kaynakları Yönetimi ve Kariyer Uygulamaları, Eğitim Yayınevi: Konya: 153-210.

Tett, R. P.; Meyer, J. P. (1993), "Job Satisfaction, Organizational Commitment, Turnover Intention, and Turnover: Path Analyses Based on Meta-Analytic Findings", Personnel Psychology, Vol. 46 No. 2: 259-293. 
Trivellas, P.; Kakkos, N.; Blanas, N.; Santouridis, I. (2015), "The Impact of Career Satisfaction on Job Performance in Accounting Firms. The Mediating Effect of General Competencies", Procedia Economics and Finance, Vol. 33: 468-476.

Tsai, Y.; Wu, S. W. (2010), "The Relationships Between Organizational Citizenship Behavior, Job Satisfaction, and Turnover Intention", Journal of Clinical Nursing, Vol. 19 No. 23-24: 3564-3574.

Turunç, Ö.; Çelik, M. (2012), "İ̧̧ Tatmini-Kişi Örgüt Uyumu ve Amire Güven- Kişi-Örgüt Uyumu Ilişkisinde Dağıtım Adaletinin Düzenleyici Rolü", ISGUC, The Journal of Industrial Relations and Human Resources, C. 14 S. 2: 57-78.

Van Dyne, L.; Cummings, L. L.; McLean Parks, J. (1995), "Extra-Role Behaviors: In Pursuit of Construct and Definitional Clarity", Research in Organizational Behavior, Vol. 17: 215-285.

Vecchio, R. P. (2006), Organizational Behavior: Core Concept, $6^{\text {th }}$ Ed., Mason, Ohio: Thomson/SouthWestern.

Vroom, V. H. (1964), Work and Motivation, New York: Wiley.

Wasti, S. A. (2000), “Örgütsel Bağlılı̆ı Belirleyen Evrensel ve Kültürel Etmenler: Türk Kültürüne Bir Bakış", (Ed. Z. Aycan), Türkiye'de Yönetim, Liderlik ve Insan Kaynakları Uygulamaları, Türk Psikologlar Derneği Yayınları: Ankara: 201-224.

Wasti, S. A. (2003), "Organizational Commitment, Turnover Intentions, and The Influence of Cultural Values", Journal of Occupational and Organizational Psychology, Vol. 76 No. 3: 303-321.

Williamson, J.; Pemberton, A.; Lounsbury, J. (2005), "An Investigation of Career and Job Satisfaction in Relation to Personality Traits of Information Professionals", The Library Quarterly, Vol. 75 No. 2: 122141.

Williams, J.; MacKinnon, D. P. (2008), "Resampling and Distribution of The Product Methods for Testing Indirect Effects in Complex Models", Structural Equation Modeling, Vol. 15 No. 1: 23-51.

Wright, T. A.; Bonett, D. G. (2007), "Job Satisfaction and Psychological Well-Being as Nonadditive Predictors of Workplace Turnover", Journal of Management, Vol. 33 No. 2: 141-160.

Yang, J. T. (2010), "Antecedents and Consequences of Job Satisfaction in The Hotel Industry", International Journal of Hospitality Management, Vol. 29 No. 4: 609-619.

Yuan, L.; Tan, X.; Huang, C.; Zou, F. (2014), "Mediating Effect of Job Satisfaction on The Relationship Between Emotional Intelligence and Perceived General Health", Social Behavior and Personality: An International Journal, Vol. 42 No. 7: 1057-1068.

Yürür, S. (2019), "Sosyal Mübadele Kuramı", (Ed. S. Yürür), Örgütsel Davranış Kuramları, BETA Yayıncilık: İstanbul: 245-279.

Zeinabadi, H. (2010), "Job Satisfaction and Organizational Commitment as Antecedents of Organizational Citizenship Behavior (OCB) of Teachers", Procedia-Social and Behavioral Sciences, Vol. 5 No. 2: 998-1003. 